\title{
COMPARING ANTIMICROBIAL ACTIVITY OF CITRUS PEEL EXTRACT AND COCONUT OIL
}

\author{
Mr. P. R. Vijaya Subramaniam \\ PG Scholar, \\ Environmental Engineering \\ Kumaraguru College of Technology \\ Coimbatore, India
}

\author{
Ms. A. Sangeetha \\ PG Scholar, \\ Environmental Engineering \\ Kumaraguru College of Technology \\ Coimbatore, India
}

\author{
Mr. T. Praveen \\ PG Scholar, \\ Environmental Engineering \\ Kumaraguru College of Technology \\ Coimbatore, India
}

\begin{abstract}
The aim of this research is to compare the antimicrobial activity of coconut oil and fermented citrus peel extract, both are antimicrobial by nature. The antimicrobial activity is tested on Escherichia coli cultured on agar media. The millimeter of zone of inhibition formed shows the antimicrobial activity. Greater the millimeter of zone of inhibition formed greater the microbial activity. Coconut oil showed zone of inhibition of $6 \mathrm{~mm}$ and citrus peel extract showed zone of inhibition of $13 \mathrm{~mm}$. This indicates that the antimicrobial activity of fermented citrus peel extract is higher than coconut oil.
\end{abstract}

Keywords- Antimicrobial activity, Fermented citrus peel extract, zone of inhibition, Bacteria.

\section{INTRODUCTION}

In India, about $40 \%$ of food produced is wasted. Approximately 20 million tons of wheat and rice are wasted in India as per the report given by United Nations Development Program. Food waste is a biodegradable waste discharged from various sources including food processing industries, households, and hospitality sector (Paritosh, 2017). The food wastes are biodegradable and it can be converted into useful products by proper treatment or procedure. The citrus fruit peel is also a type of food waste. Instead of throwing it away, it is fermented and its full use is obtained. This study creates an awareness to use the food waste without throwing that as a waste.

An agent that kill or prevents the growth of microorganisms is an antimicrobial agent. The process in which microorganisms break the organic matter into alcohol and organic acids to obtain energy and stay alive is called fermentation. It uses bacteria or yeast to convert sugar to gases, alcohol and acids. In simple, it is the breakdown of larger organic compounds to smaller ones. This process is used in the production of drugs, alcohols and extracts.
Lemon is one of the important medicinal plant. It has antibacterial and anticancer potentials in extract of leaves, stem, root and flower. The citrus fruits peel is rich in polymethoxylated flavones and flavanones than other plants. These play an important physiological and ecological role, and also of commercial interest due to their various applications in food and pharmaceutical industries. The citrus peel oils show strong antimicrobial activity (Saramanda, 2017). The primary objective of this is,

- Extraction of fermented citrus fruit peel and collection of fresh coconut oil.

- Testing and comparing the antimicrobial activity of citrus peel extract and coconut oil.

\section{Methods AND Materials}

For this comparative study, fermented citrus fruit peel extract and fresh coconut oil are the main ingredients required.

\section{A. Preparation of Extract}

For this study a batch of fermented lemon peel extract is prepared. The materials and ingredients required are, air tight plastic or glass container, citrus peel, jaggery, water. The ingredients required are shown in fig.1. The ingredients are taken in the ratio of 15:10:3:1. Fresh citrus fruit peels of required amount is collected first. An air tight glass container of one-liter capacity (which is 15\%) is taken in which $10 \%$ of water, $3 \%$ of jaggery is mixed and remaining $1 \%$ is left free and the lid is closed tightly. The entire process takes up to 90days for completion. The entire time period is divided into two. For the first 30 days, aerobic fermentation takes place. During this period, gas is generated due to fermentation which is to be removed by opening and closing the lid daily. After 30 days, no gas is generated during the process. Once after completion of 30days, the lid is tightly closed and after completion of 60 days, the completed product is obtained. 


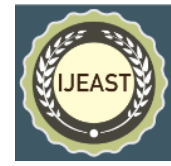

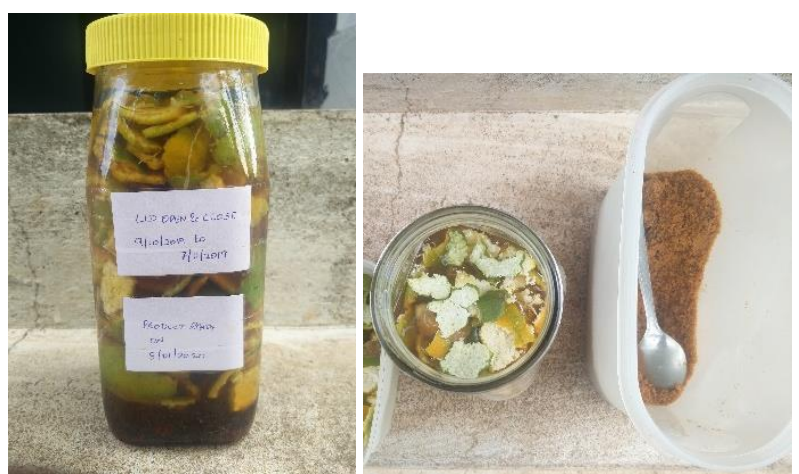

Fig. 1. Enzyme extraction setup

\section{B. Collection of Fermented Extract}

As discussed, the citrus peel extract was prepared by fermentation of fresh citrus peels with water and jaggery in an air tight glass container. After 90days, the process was completed and we would obtain clear enzyme and pulpy enzyme. The solid residuals were filtered and clear solution is extracted. The collected extract is shown in fig.2. During fermentation, carbohydrates was converted to volatile acids and the organic acids present in the citrus peel also leached out into fermented solution (Nazim, 2013).

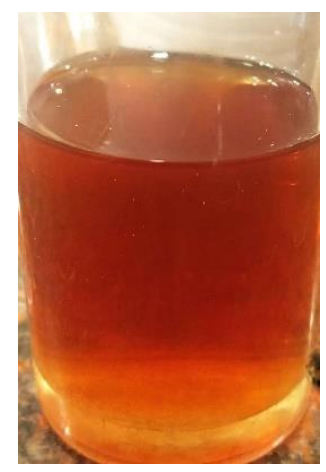

Fig. 2. Fermented citrus fruit peel extract

\section{Preparation of Agar Media}

For preparation of media, nutrient agar is used. The procedure for preparation of media is as follows, measure $100 \mathrm{ml}$ of distilled water in a clean $250 \mathrm{ml}$ capacity conical flask. Dissolve the media components in the following proportion, peptone $(5 \mathrm{~g})$, beef extract $(3 \mathrm{~g})$, Nacl $(5 \mathrm{~g})$, Agar $(15 \mathrm{~g})$ and $1000 \mathrm{ml}$ of distilled water. Heat the contents to dissolve completely. Check the $\mathrm{pH}$ of the medium and adjust if needed using acid or alkaline solution. Then, plug the conical flask with non-absorbent cotton and Keep the conical flask inside the autoclave for sterilization at $121^{\circ} \mathrm{C}$ for $15-20$ minutes. After sterilization, it is poured onto sterile petri plates and allowed for solidification.

\section{Culture Plating}

The bacteria selected for this study is Escherichia coli. For culturing of Escherichia coli, a 24 to 48-hour broth culture of the particular bacteria is taken. Plate culturing is done by the following procedure, Pipette $0.1 \mathrm{ml}$ of the respective bacterial culture onto the center of a tryptic agar plate. Dip the Lshaped glass rod into a beaker of ethanol pass the ethanolsoaked spreader through the flame to burn off the alcohol.
Then, by the sterilized spreader, spread the bacterial sample evenly over the agar surface, making sure the entire surface of the plate has been covered. At the center of this plate $15 \mu \mathrm{l}$ of coconut oil and citrus peel extract are added in two separate plates respectively. The plates were incubated at $37^{\circ} \mathrm{C}$ for 24hours. The antimicrobial activity of both coconut oil and citrus peel are expressed in terms of diameter for the zone of inhibition in millimeter.

\section{ReSUlts AND Discussion}

The antimicrobial activity of fermented citrus fruit peel and coconut oil is given in table I.

TABLE I. ANTIMICROBIAL ACTIVITY

\begin{tabular}{|c|c|c|}
\hline Name of bacteria & $\begin{array}{c}\text { Antimicrobe } \\
\text { used }\end{array}$ & $\begin{array}{c}\text { Zone if } \\
\text { inhibition }(\mathbf{m m})\end{array}$ \\
\hline $\begin{array}{c}\text { Escherichia } \\
\text { coli }\end{array}$ & Coconut Oil & 6 \\
\hline $\begin{array}{c}\text { Escherichia } \\
\text { coli }\end{array}$ & $\begin{array}{c}\text { Fermented citrus } \\
\text { peel extract }\end{array}$ & 13 \\
\hline
\end{tabular}

From the above table it is understood that, the use of coconut oil as antimicrobe created a zone of inhibition of only $6 \mathrm{~mm}$ while the fermented citrus fruit peel as an antimicrobe created a zone of inhibition of $13 \mathrm{~mm}$. This shows that the antimicrobial activity of citrus fruit peel is greater when compared with coconut oil which is a natural antimicrobe. The following fig. 3 shows the zone of inhibition of different antimicrobe in graphical representation.

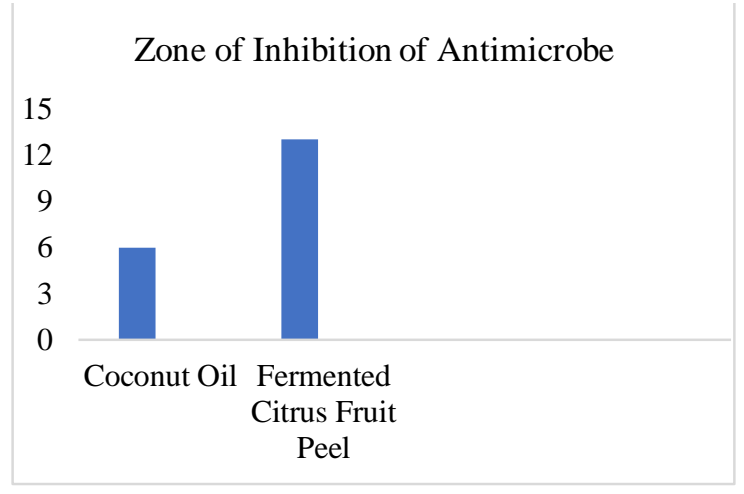

Fig. 3. Graphical representation of antimicrobial adtivity

\section{CONCLUSION}

In this study, the antimicrobial activity of citrus fruit peel extract and coconut oil was compared. The procedure for extraction of fermented citrus fruit peel and culturing of Escherichia coli bacteria was studied. The antimicrobial activity was found by measuring the diameter of zone of inhibition. The result showed that the zone of inhibition of fermented citrus fruit peel was greater than that of coconut oil. Thus, it may be concluded that the antimicrobial activity of fermented citrus fruit peel is higher than the coconut oil.

\section{ACKNOWLEDGMENT}

The authors are grateful to the management of Kumaraguru College of technology, Coimbatore, India, for 


\section{International Journal of Engineering Applied Sciences and Technology, 2020 \\ Vol. 4, Issue 11, ISSN No. 2455-2143, Pages 279-281 \\ Published Online March 2020 in IJEAST (http://www.ijeast.com)}

the facilities made available for this study. Thanks to our family and friends for their support.

\section{REFERENCES}

[1] C.R. Jo, B.J. Park et al. (2004), 'Antibacterial and Antifungal Activity of Citrus (Citrus unshiu) Essential Oil Extracted from Peel By-products', Journal of Food Science and Biotechnology, Vol.13, No.3, pp.384-386.

[2] Fazana Nazim, V. Meera (2013), 'Treatment of Synthtic Greywater Using 5\% and 10\% Garbage Enzyme Solution',Bonfring International Journal of Industrial Engineering and Management Science, Vol.3, No.4, pp.111-117.

[3] Ferdinan Pasaribu, Irma Ervina et al. (2018), 'The Effictiveness Antimicrobial Activity Test of Citrus Peel Extract on Some Periodontal Pathogenic Bacteria (In Vitro)', International Journals of Applied Dental Sciences, Vol.4, No.3, pp.146-150.

[4] F.Gulay Kirbaslar, Aydin Tavman et al. (2009), 'Antimicrobial Activity of Turkish Citrus Peel Oils', Vol.41, No.6, pp.3207-3212.

[5] Geetha Saramanda, Jyothi Kaparapu (2017), 'Antimicrobial Activity of Fermented Citrus Fruit Peel Extract', Journal of Engineering and Research, Vol.7, No.11, pp.25-28.

[6] J. Maruti Dhanavade, B. Chidamber Jalkute et al. (2011), 'Study Antimicrobial Activity of Lemon (Citrus lemon L.) Peel Extract', British Journal of Pharmacology and Toxicology, Vol.2, No.3, pp.119-122.
[7] Junab Ali, Biswajit Das et al. (2017), 'Antimicrobial Activity of Lemon (Citrus Limon) Extract', International Journal of Current Pharmaceutical Research, Vol.9, No.4, pp.79-82.

[8] Kunwar Paritosh, K.Sandeep Kushwaha et al. (2017), 'Food Waste to Energy: An Overview of Sustainable Approaches for Food Waste Management and Nutrient Recycling', BioMed Research International.

[9] Nada Khazal Kadim Hindi, Zainab Adil Ghani Chabuck (2013), 'Antimicrobial Activity of Different Aqueous Lemon Extracts', Journal of Applied Pharmaceutical Sciences, Vol.03, No.0, pp.74-78.

[10] R. Sandra Fuselli, B. Susana Garcia de la Rosa et al. (2008), 'Chemical Composition and Antimicrobial Activity of Citrus Essences on Honeybee Bacterial Pathogen Paenibacillus larvae, The Casual Agent of American Foulbrood', World Journal of Microbiology and Biotechnology, Vol.24, No.2067, DOI: 10.1007/s11274-008-9711-9.

[11] Shahid Mahmud, Muhammad Saleem et al. (2011), 'Volatile Components, Antioxidant and Antimicrobial Activity of Citrus acida var. Sour Lime Peel Oil', Journal of Saudi Chemical Soceity, Vol.2, No.3, pp.195-198.

[12] S. Madhuri, A.U. Hedge et al. (2014), 'Antibacterial Activity of Citrus sinensis and Citrus aurantium Peel Extracts', Journal of Pharmaceutical and Scientific Innovation, Vol.3, No.4, pp.366-368. 